\title{
Planning of Keraton Cultural Tourism in Cirebon, Indonesia Based on Graphical User Interface (GUI)
}

\author{
Dini Rosmalia ${ }^{1 *}$, Euis Puspita Dewi ${ }^{2}$ and Febri Maspiyanti ${ }^{3}$ \\ ${ }^{1}$ Faculty of Engineering, Architecture, University of Pancasila, Jalan Lenteng Agung Timur 12630, \\ Jakarta Selatan, Indonesia \\ ${ }^{2}$ Faculty of Engineering, Architecture, Universitas Persada Indonesia YAI, Jalan Salemba Raya 7-9, \\ 10440, Jakarta Pusat, Indonesia
}

${ }^{3}$ Faculty of Engineering, Information Technology, University of Pancasila, Jalan Lenteng Agung Timur 12630, Jakarta Selatan, Indonesia

\begin{abstract}
Cirebon is one of the cities in Indonesia with a unique cultural landscape and is well known as a cultural and religious tourism area. The culture of the palace community in Cirebon is strongly influenced by the Sultanate of Cirebon so the various cultural rituals held by most of the people can be seen in places that have links with the Palace. The rituals and locations of the event are an interesting cultural element to serve as tourism assets. Graphical User Interface based tourism planning becomes essential to broaden the knowledge and insight of society to cultural and religious tourism in Cirebon, not only for the people of Cirebon but also Indonesia and abroad. In this study, a map of Cirebon tourist maps will be displayed in the form of Geographic Information System (GIS) and Graphical User Interface (GUI) on Android-based smartphone operation
\end{abstract}

\section{Introduction}

Indonesia is a country that possesses many regions with diverse cultural uniqueness. This uniqueness can be seen from the variety of ornaments, building, and landscape. One of the areas that possess unique and historical value cultural landscape is Cirebon. Cirebon possesses many faces consist of the coastal area, keraton, colonial, and religious cultures. Keraton culture has a significant influence on the formation of the landscape and the community life in Cirebon [9, 10]. Various cultural tradition rituals practiced by the majority of Cirebon community can be seen routinely particularly on major Moslems religious days [13] [20].

Keraton cultural life has become part of community life manifested tangible and intangible. The form of the intangible cultural element is traditional ritual activities, such as 1 Suro, muludan, sawalan, etc. On the other hand, the kind of tangible elements is the place for conducting traditional ritual activities that have a connection with the keraton [16]. In

\footnotetext{
* Corresponding author: dinirosmalia@univpancasila.ac.id
} 
general, those two elements are unique, distinctive, and heritage-valued elements so that they are potential to be the leading tourism resources in Cirebon [17].

Nowadays, these leading cultural tourism resources related to keraton Cirebon have been widely known, especially among domestic tourists [14]. Those tourism resources are potential to be improved to a wider scale, i.e., international market segment. However, publication and promotion of that tourism resource are limited, especially information on the holding of traditional ritual activities, specifically those related to keraton culture. Therefore, this research aims to produce information planning on Cirebon keraton cultural area-based on Graphical User Interface using Geographic Information System and information technology.

\section{Methodology}

This research consists of 2 (two) phases, i.e.:

1. The stage of mapping the keraton cultural tourism area. Data collection was done with survey and observation on the cultural area to obtain potential tourism object. Then, the purpose was assessed based on various categories and sub-categories which are the result of modification from the previous researchers $[11,12,14,15]$, as presented in Table 1.

Table 1. Category and Sub-Category of the Assessment of Potential Cultural Tourism Object Source: Modification of the many previous research [11, 12, 14, 15]

\begin{tabular}{|l|ll|}
\hline \multicolumn{1}{|c|}{ Category } & \multicolumn{1}{c|}{ Sub-category } \\
\hline Historical Value & - & $\begin{array}{l}\text { Possesses a relationship with the leading local figure } \\
\text { Location with historical value }\end{array}$ \\
& - & $\begin{array}{l}\text { Possesses historical meaning } \\
\text { Possesses meaning related to religion and beliefs of local community } \\
\text { and visitors }\end{array}$ \\
\hline $\begin{array}{l}\text { Harmony } \\
\text { between Culture } \\
\text { and } \\
\text { Environment }\end{array}$ & - & $\begin{array}{l}\text { Object and attraction have a positive impact on local culture } \\
\text { Object and attraction have a positive effect on the environment }\end{array}$ \\
\hline $\begin{array}{l}\text { Uniqueness and } \\
\text { Attractiveness } \\
\text { Level }\end{array}$ & - & $\begin{array}{l}\text { Contain objects that attract many people. } \\
\text { Contain exciting activities and are potential to involve many visitors }\end{array}$ \\
\hline Social Function & - & $\begin{array}{l}\text { Cultural activities involve plenty of interactions with the local } \\
\text { community } \\
\text { Cultural activities do not cause a lousy impact on local community } \\
\text { social life }\end{array}$ \\
\hline
\end{tabular}

2. The phase of designing application using Use Case Diagram modeling to provide information on the global functionality of the application that will be developed for Cultural Tourism Object in Cirebon. Information that will be shown is 1. Cultural Tourism Object, 2) Cultural Tourism Route, 3) Cultural tourism event, 4) Supporting Tourism Object (Figure 1).

3. Implementation Phase contains 2 subphases, i.e., digitalization and Android-based coding. This phase produces a file with app format (application package file). 


\section{The mapping of potential tourism object}

\subsection{The level of the potency of cultural tourism object}

The assessment of cultural landscape elements was done based on 3 (three) indicators, i.e., meaningful content with historical value, the harmony of elements with keraton culture and the environment of the tourism object location, object uniqueness and attractiveness, and object compatibility as a social forum. The assessment on tourism potency has chosen 11 (eleven) tourism objects related to keraton culture. Those 11 objects are divided into very potential tourism object and potential tourism object groups. The very potential tourism objects are 1) Astana Gunungjati, 2) Astana Gunung Sembung, 3) Kasepuhan Keraton, 4) Kanoman Keraton, 5) Kacirebonan Keraton, and 6) Sang Cipta Rasa Mosque. Whereas the potential tourism objects are: 1) Jagabayan Mosque, 2) Panjunan Mosque, 3) Talun cemetery complex, 4) Ki Buyut Trusmi, and 4) Plangon cemetery. These three objects are located in Cirebon Regency and considered as supporting tourism objects (Fig.1).

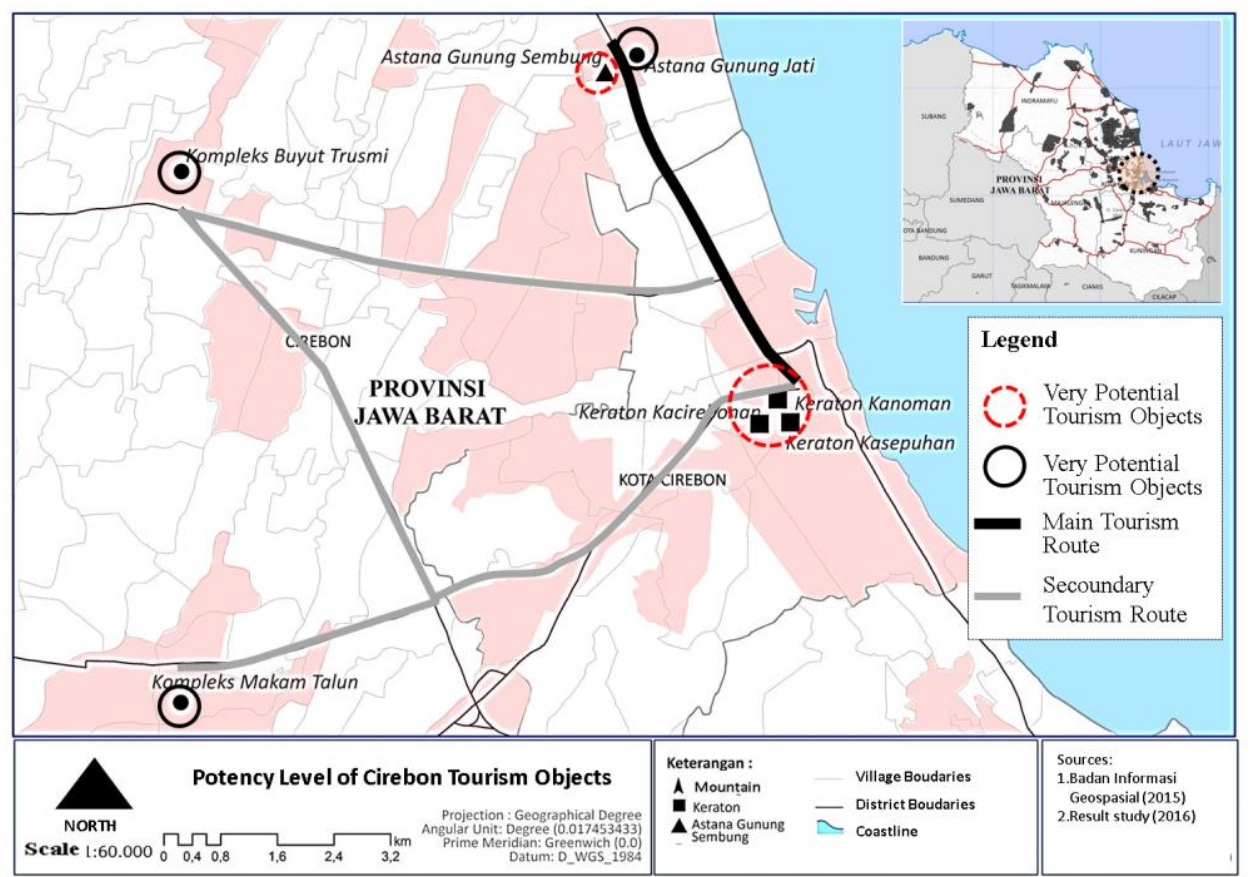

Fig. 1. Potential Tourism Spatial Zone

Source: Rosmalia and Prasetya [14]; Rosmalia [16]; BIG [19]

\subsection{Tourism Spatial Planning Based on Potential Cultural Landscape Elements}

The analysis of the potency of the area as tourism area shows that there are zones potential to be developed into tourism area, i.e., Gunungjati area in the northern region and keraton area in the southern part of Cirebon City. Gunungjati region includes Astana Gunung Sembung and Astana Gunungjati areas, whereas Southern region comprises Kasepuhan, Kanoman, and Kacirebonan keratons. The condition of the potential resources is seen in the result of a mapping presented by Rosmalia and Prasetya [14], and Rosmalia [16]. Fig. 2 
shows a very potential spatial zone extending from the North, in Cirebon Regency, to the southern region of Cirebon City, connected by tourism route of Siliwangi Street and Karanggetas Street. Those two very potential tourism areas are connected by sacred tourism route, i.e., Karanggetas Street. In this route, there is also religious tourism objects potential of supporting tourism objects, such as At-taqwa Mosque, Panjunan Mosque, and Jagabayan Mosque.

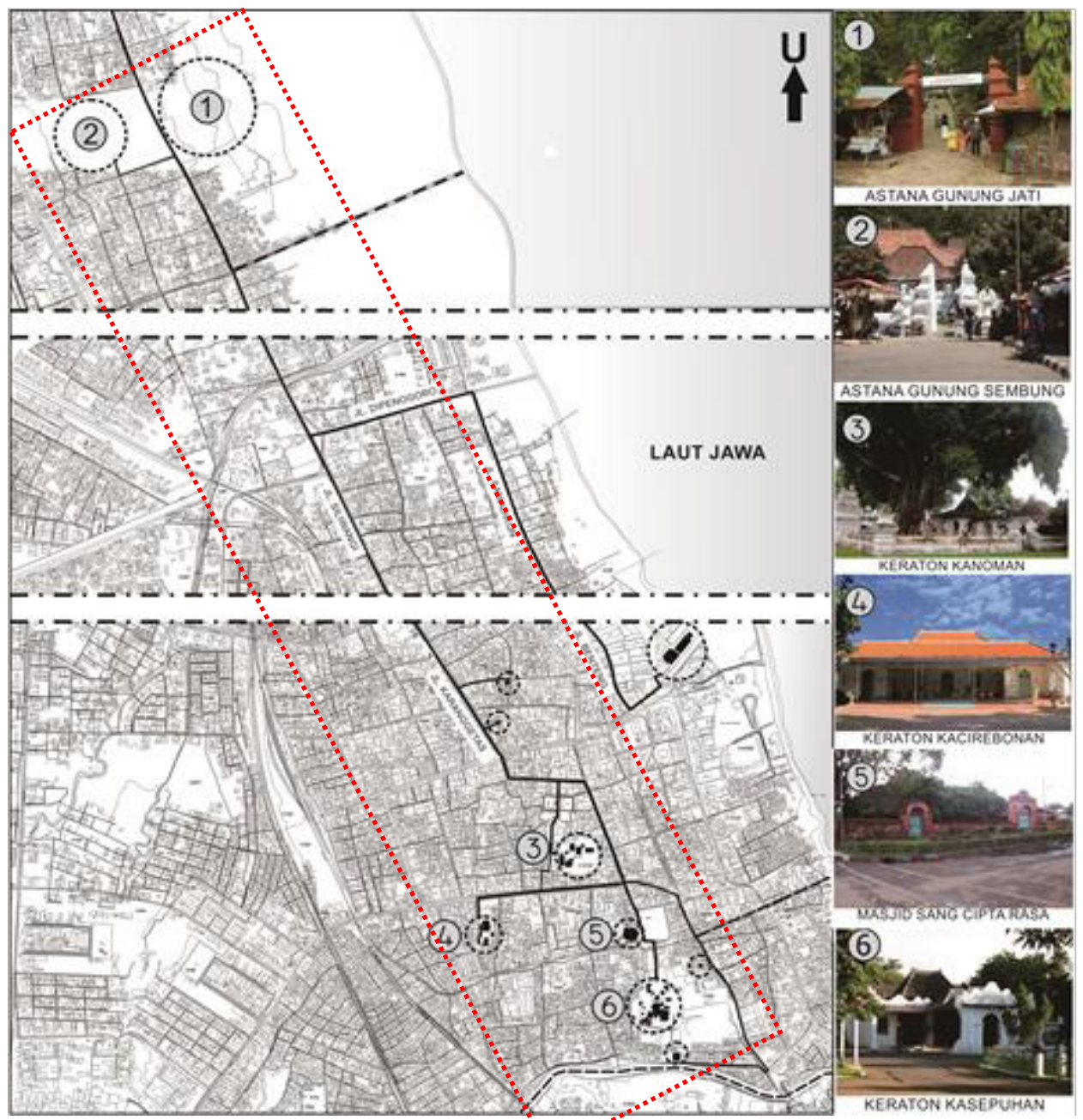

Fig. 2. Tourism Object in Cirebon Obyek Wisata di Cirebon

Source: Rosmalia and Prasetya [14]; Rosmalia [16]; Dewiyanti and Rosmalia [18]

The keraton cultural tourism space that is formed is part of the development of Cirebon city tourism space, within which there are also other tourism objects, such as religious, culinary, and shopping tourism objects. Those objects are complementing one with another and become a unity. Therefore, in the mapping of this keraton cultural tourism space, other tourism objects become companions that will add to the attractiveness for the tourists to come to Cirebon. 


\section{Cirebon cultural tourism}

\subsection{Application designing using "use case diagram modeling"}

After mapping the potential tourist area, the next phase is designing the system using Use Case Diagram [1]. This keraton cultural tourism application functionality can be seen in Use Case Diagram in Fig. 3. These functionality namely:

1. Religious tourism area information. This information contains a list of religious tourism sites displayed in the form of markers on the map. If the User clicks on any of the tags, the application will display the information about related religious tourism site along with the list of nearby hotels.

2. Destinations route information. This application provides routes information between one and another cultural tourism site. The information that will be displayed is the distance between the starting location and the destination site along with the types of transportation that can be used.

3. Religious events information. This information is a list of events that contain the event title or theme, date, time, and other related information of a religious event. Event list can be managed by an admin.

4. Culinary area information. This information is a list that will be displayed in the form of markers on the map. If the User clicks on any of the markers, the application will display the information about culinary information of the selected marker.

5. Events info management (for Admin). This function can only be accessed by Administrator. The Administrator can manage the events such as add, edit, and delete the event list.

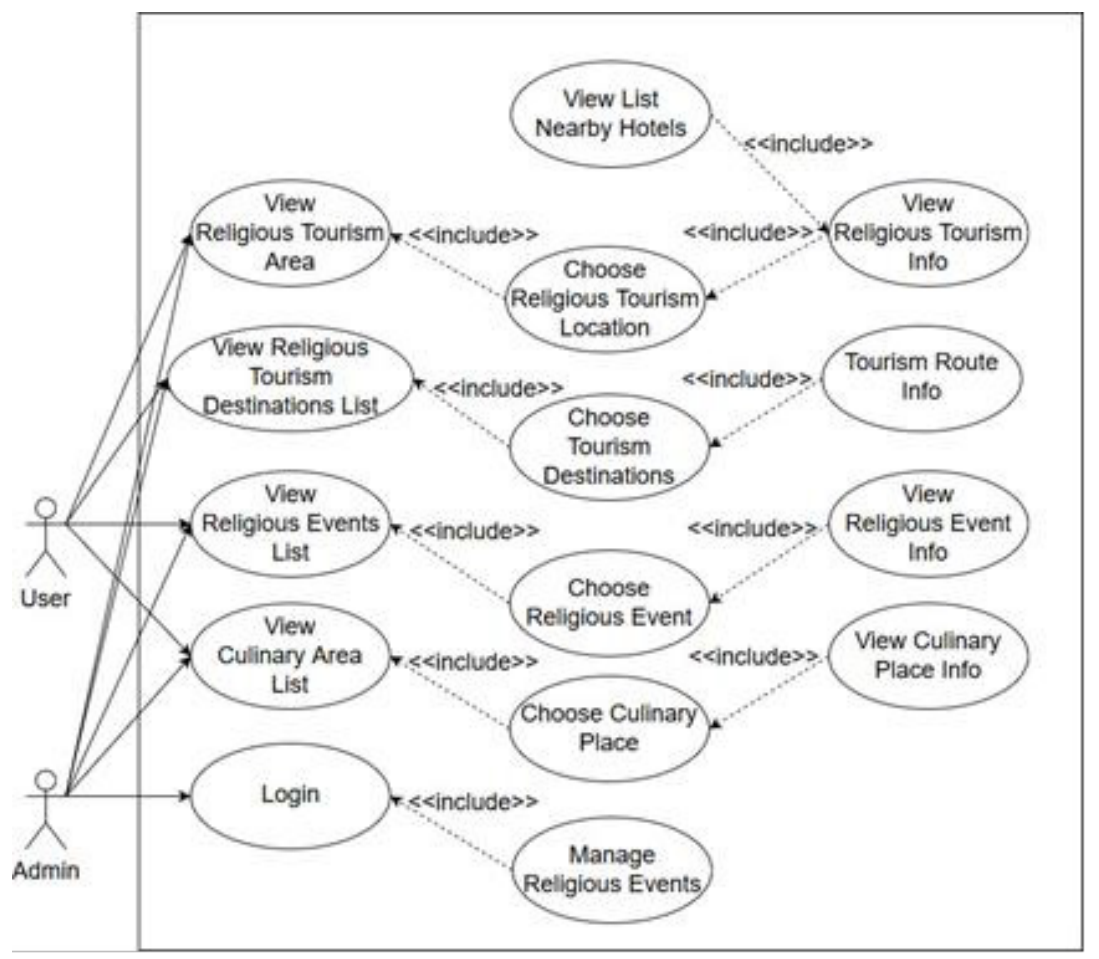

Fig 3. Keraton Cultural Tourism application Use Case Diagram 


\subsection{User interface of cirebon cultural tourism}

Other studies conducted by Palacios [7] and Rutherford [8] utilizing Geographic Information System (GIS) and mobile technology in Tourism issue. This GIS development also supported by another literature study such as understanding GIS [5, 6], how to build mobile GIS [4], and Android Programming [2, 3].

This Cirebon cultural tourism geographic information system was developed using ArcGIS (https://www.arcgis.com/features/index.html). The user interface for cultural tourism area can be seen in Fig. 4. This page includes a map with religious places tagging location. Each tagging location included related information that can be accessed by clicking each tagging location on the map. While the culinary area can be seen Fig.5.

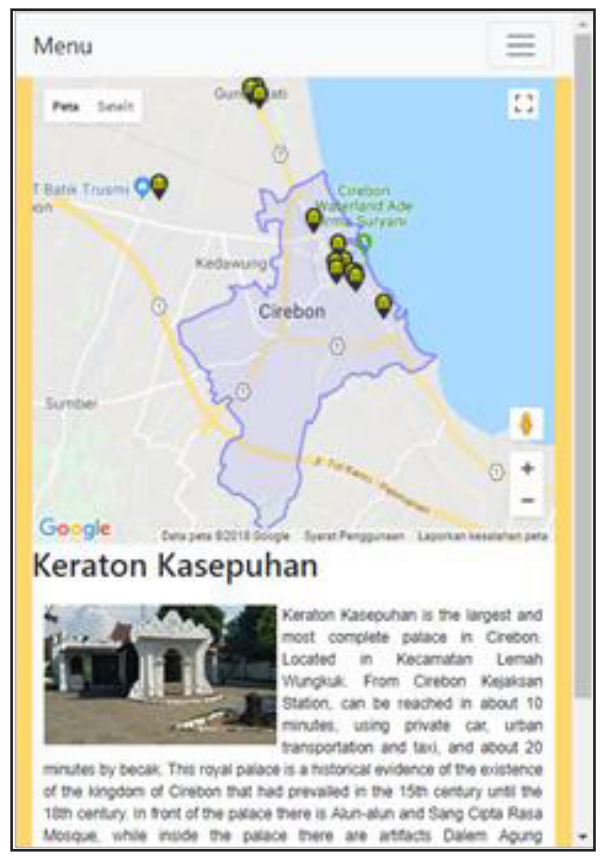

Fig. 4. Cultural Tourism Area

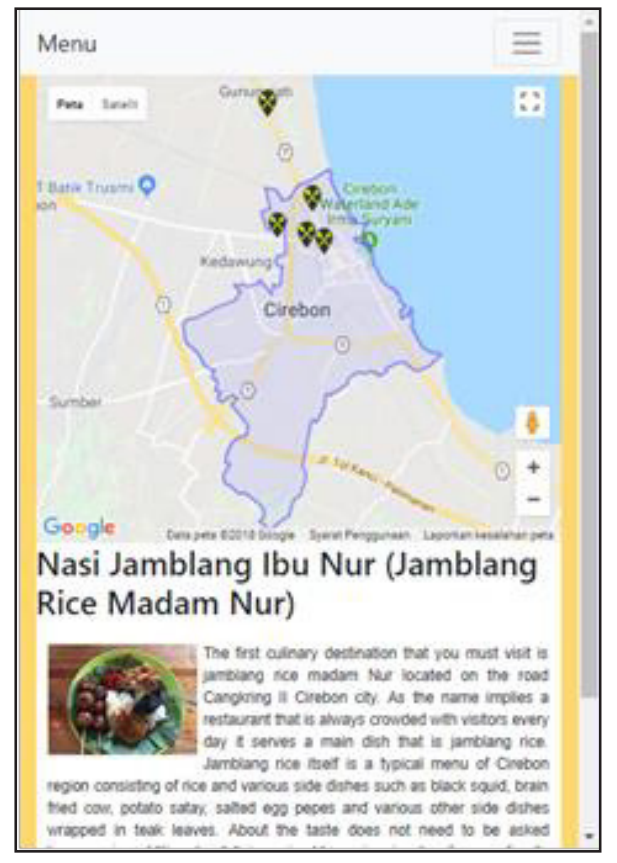

Fig. 5. Culinary Area

Destinations route information user interface can be seen in Fig.6. The markers show the starting and ending location, and the blue line is the route that has to be taken from the starting location to the desired destination. The Religious events information user interface contains the event title, date, time, and others related information see Fig. 7 below. 


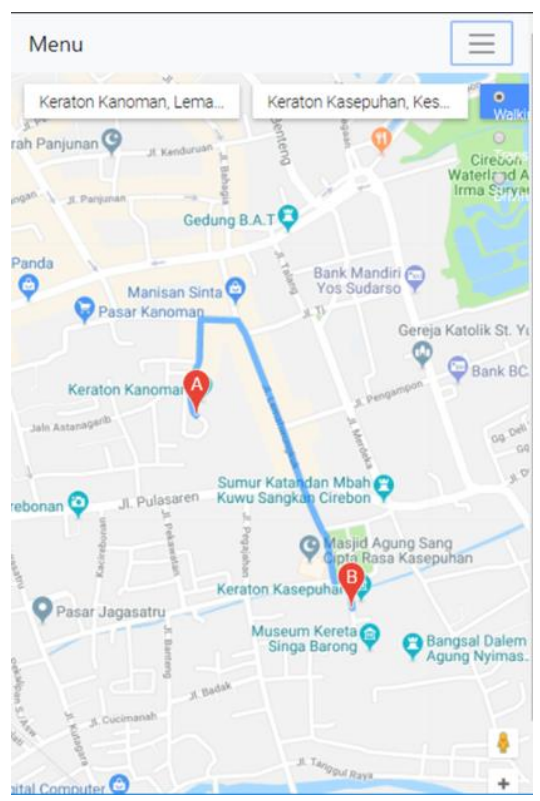

Fig. 6. Destination Route Information

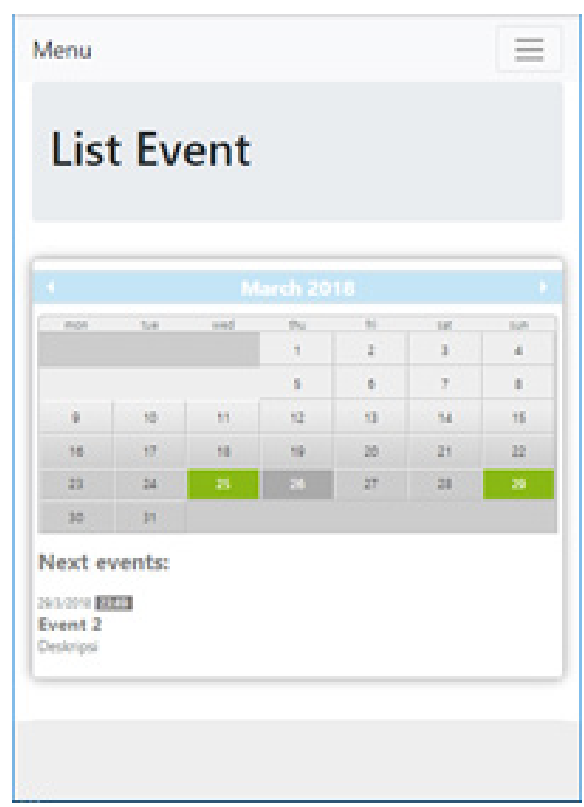

Fig.7. Culinary Area

A user interface that can be seen in Fig. 8 to 10 can only be accessed by Administrator. Fig. 8, shows the login form for the Administrator to manage the Events list. Fig. 9 shows the administrator home user interface, contains a list of events with manage function button. The last user interfaces are Add Event and Edit Event interface. Add Event user interface comprises three fields (attributes), i.e., title, date, and descriptions, and one Save button. Edit Event user interface can be used to Edit or Update an event.

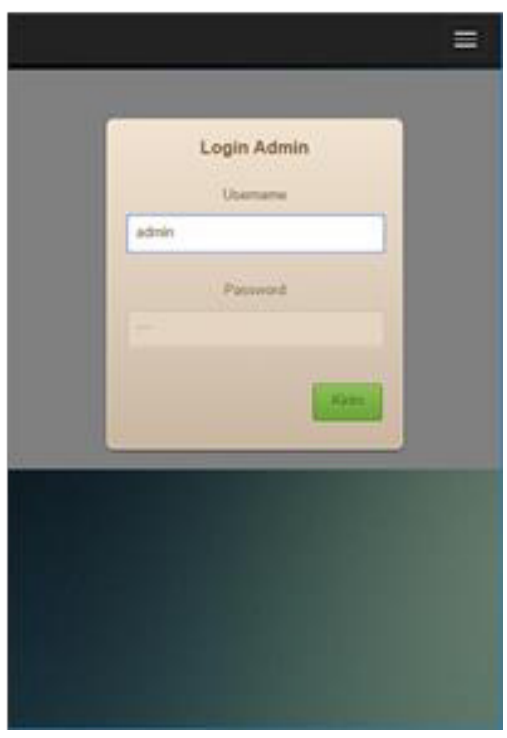

Fig. 8. Administrator Login User Interface

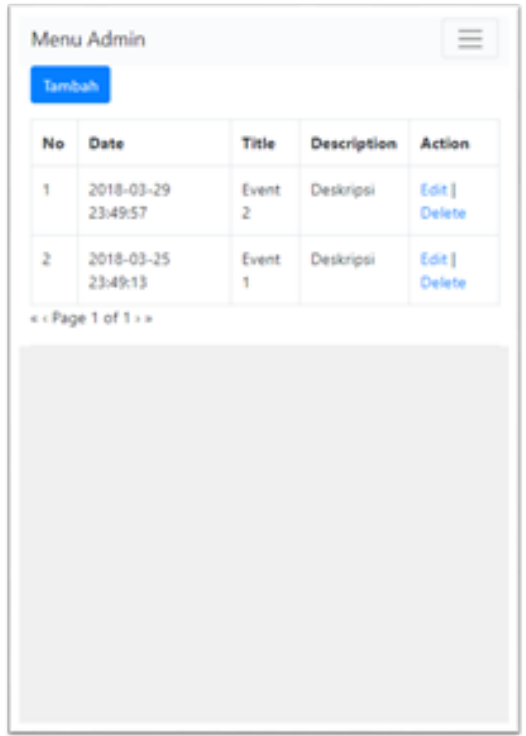

Fig. 9. Administrator Home User Interface 


\section{Conclusions and recommendation}

The distribution pattern of cultural tourism objects related to Cirebon keraton that belong to the very potential category is extended from the South of Cirebon city to the North area in the Cirebon Regency. The position of this cultural tourism object forms a tourism space that is very potential to be developed as the leading tourism resources both for Cirebon City (Kesepuhan keraton, Kanoman keraton, and Kacirebonan keraton) and Cirebon Regency (Astana Gunung Sembung and Astana Gunungjati). The tourism resource is very potential to increase Regional Revenue for Cirebon Regency and Cirebon City. Therefore, the application of information system on the position and the schedule of leading tourism resources along with its supporting tourism can assist local and foreign tourists in visiting Cirebon. With the help of this application tourists can efficiently plan their trips, before or when they visit Cirebon.

The authors gratefully acknowledge that the present research is supported by the Ministry of Research, Technology and Higher Education of the Republic of Indonesia. The support is under the research grant "Penelitian Strategis Nasional" of the Year 2018.

\section{References}

1. R. Miles, K. Hamilton. Learning UML 2.0: A Pragmatic Introduction to UML. O’Reilly Media Inc (2006)

2. P. Deitel, H. Deitel, A. Deitel, Android: How to Program. Pearson Education (2013).

3. J. Annuzzi Jr., L. Darcey, S. Conder. Introduction to Android Application Development: Android Essentials. Addison Wesley (2015).

4. E. Pimpler, B. Web. Mobile ArcGIS Server Applications with JavaScript. Packt Publishing Ltd. (2014)

5. L. Zink. Chapter 2: What is Geographic Information and GIS?. In Draft: Nebraska Guidebook for a Local Government Multipurpose Land Information System. Nebraska Advisory Committee on Standards for Multipurpose Land Information Systems (2000).

6. I. Heywood, S. Cornelius, S. Carver. AnIntroduction to Geographical Information Systems. Pearson Education Limited (2012).

7. R. Comolo-Palacios, et-al. Towards a social and context-aware mobile recommendation system for tourism. Elsevier (2017)

8. J. Rutherford, H. Kobryn, D. Newsome. A case study in the evaluation of geotourism potential through geographic information systems: application in a geology-rich island tourism hotspot. Current Issue in Tourism. Taylor and Francis Group (2013)

9. K. Adeng, H. Wiwi, H. Wiryono, Erwantoro. Kota DagangCirebon sebagai Bandar Jalur Sutra. Jakarta: Direktorat Sejarah dan Nilai Tradisional Direktorat Jenderal Kebudayaan Departemen Pendidikan dan Kebudayaan (1998)

10. H. M. Ambary. Peranan Cirebon sebagai Pusat Pengembangan dan Penyebaran Islam. S. Zuhdi. Cirebon Sebagai Bandar Jalur Sutra: Kumpulan Makalah Diskusi Ilmiah (éd. 2nd ). Jakarta: Depertemen Pendidikan dan Kebudayaan, 141-162 (1998)..

11. C. A. Gunn, T. Var. Tourism Planning: Basics, Concepts, Cases (éd. 4rd ). New York: Routledge (2002)

12. E. Inskeep. Tourism Planning: An Integrated and Sustainable Development Approach. New York: Van Nostrand Reinhold (1991)

13. A. G. Muhaimin. The Islamic Traditions of Cirebon: Ibadat and Adat Among Javanese Muslims. Canberra: The Australian National University (2006) 
14. D. Rosmalia, L. E. Prasetya. Development of Cultural Tourism Area Based on the Spiritual Space of Cirebon Keraton. IOP Conference Series: Earth and Environmental Science. 126 012076. IOP Publishing Ltd (2018).

15. D. Rosmalia, S. Nurisyah, Y. Prihayati. Development Planning for Ecotourism. Saarbrucken, Germany: LAP Lambert Academic Publishing GmbH \& Co. KG (2012)

16. D. Rosmalia. Pengaruh Kebudayaan Keraton Terhadap Pola Ruang Lanskap Budaya Cirebon. Bandung : Institut Teknologi Bandung (ITB). [Dissertation]. (2016)

17. S. T. Sulistiyono. Perkembangan Pelabuhan Cirebon dan Pengaruhnya Terhadap Kehidupan Sosial Ekonomi Masyarakat Kota Cirebon 1859-1930. Yogyakarta: Program Pancasarjana Universitas Gajah Mada (1994)

18. D. Dewiyanti, D. Rosmalia. Begging and tourism: between visual imagery and social reality. IOP Conference Series: Materials Science and Engineering (2018)

19. Badan Informasi Geografis Indonesia (BIG). Cirebon City Map. Indonesia (2015)

20. D. Rosmalia, L. E. Prasetya. Kosmologi Elemen Lanskap Budaya Cirebon. Seminar Heritage. IPLBI [proceeding] (2017) 